\title{
EFEKTIVITAS SERBUK BIJI PEPAYA (Carica Papaya L.) TERHADAP KEMATIAN JENTIK (LARVA) Culex sp.
}

\section{EFFECTIVENESS OF PAPAYA SEED POWDER (Carica Papaya L.) ON DEATH TYPES (LARVA) Culex sp.}

\author{
Ahmad, Arif Adriyanto \\ Poltekkes Kemenkes Banten \\ Korespondensi: ahmad@poltekkesbanten.ac.id
}

\begin{abstract}
Vector control, especially filariasis disease usually uses synthetic chemical insecticides, this is a risk of resistance in mosquitoes Culex sp.. as the main vector. Papaya Seed Powder (Carica Papaya L.) is very good for use as a repellent for larvae Culex sp.because of the poisons found in papaya seeds called karpaina alkaloids. The purpose of this study was to determine the effectiveness of papaya seed powder as larvacide Culex sp. This study was an experimental laboratory with a research design post-test design with control. The treatment of dose variation is (60 mg, $90 \mathrm{mg}, 120 \mathrm{mg}, 150 \mathrm{mg}$ ) and the samples were taken are instar III and IV larvae. To determine the number of treatments and repetitions using the Randomized Block Design (RBD) pattern where the treatment in this study was four treatments with six repetitions. Each treatment contained 20 larvae and performed six repetitions. The results of this study are the number of percentage deaths respectively at $58.33 \%, 78.33 \%, 87.50 \%$, 94.16\%. The results of the statistical analysis using the SPSS application with the One Waytest ANOVA showed a significance of 0,000, which means that the p-value <0.005, which indicates that the powder of papaya seeds (Carica Papaya L.) is effective for killing larvae Culex sp. For future researchers and related stakeholders, it is recommended to use papaya seed powder (Carica Papaya L.) as a natural bioinsecticide and look for other natural bioinsecticides that are environmentally friendly.
\end{abstract}

Keywords: Papaya Seed Powder, Larva Culex sp

\section{ABSTRAK}

Pengendalian vektor khususnya vector penyakit filariasis biasanya menggunakan bahan insektisida kimia sintetik, hal ini beresiko terjadi resistensi pada nyamuk Culex sp. sebagai vektor utama. Serbuk Biji Pepaya (Carica Papaya L.) sangat baik untuk digunakan sebagai penolak larva Culex sp.karena racun yang terdapat dalam biji pepaya yang disebut alkaloid karpaina. Tujuan penelitian ini untuk menentukan efektivitas serbuk biji pepaya sebagai larvasida Culex sp. Desain penelitian menggunakan post test desain with control. Perlakuan variasi dosis yaitu $60 \mathrm{mg}, 90 \mathrm{mg}, 120 \mathrm{mg}$, $150 \mathrm{mg}$.Sampel yang diambil adalah larva instar III dan IV. Jumlah perlakuan dan pengulangan menggunakan pola Rancangan Acak Kelompok (RAK) dimana perlakuan pada penelitian ini sebanyak empat perlakuan dengan enam kali pengulangan. Setiap perlakuan berisi 20 larva dan melakukan enam kali pengulangan. Hasil penelitian ini menunjukan jumlah persentase kematian berturut-turut sebesar 58,33\%, 78,33\%, 87,50\%, 94,16\%. Hasil analisis statistik dengan uji One Way 
ANOVA menunjukkan nilai $\mathrm{p}$ value $=0,000$ yang artinya bahwa nilai $\mathrm{p}$ value $<0,005$, yang mengindikasikan bahwa serbuk biji pepaya (Carica Papaya L.) efektif untuk membunuh larva Culex sp. Bagi peneliti selanjutnya dan pemangku kebijakan terkait disarankan untuk menggunakan serbuk biji pepaya (Carica Papaya L.) sebagai bioinsektisida alami dan mencari bioinsektisida alami lain yang ramah lingkungan.

\section{Kata Kunci: Serbuk Biji Pepaya, Jentik Culex sp}

\section{PENDAHULUAN}

Nyamuk merupakan salah satu jenis serangga yang dapat merugikan manusia karena perannya sebagai vektor penyakit. Salah satu jenis penyakit yang disebabkan oleh nyamuk, yaitu filariasis yang ditularkan melalui nyamuk Culex sp.(Lestari, 2016). Filariasis merupakan salah satu penyakit tertua yang paling melemahkan yang dikenal di dunia. Indonesia termasuk salah satu negara endemis filariasis. Berdasarkan data yang dilaporkan dinas kesehatan provinsi di Indonesia kasus filariasis kronis sepuluh tahun terakhir cenderung meningkat. Pada tahun 2005 ada 8.243 kasus filariasis dan pada tahun 2014 meningkat menjadi sebanyak 14.932 orang dari 418 kabupaten/kota di 34 provinsi. Kasus klinis filariasis dilaporkan cenderung meningkat dari tahun ke tahun disebabkan banyaknya kasus yang baru ditemukan seiring dengan kabupaten/kota yang melaksanakan pendataan sasaran sebelum pemberian obat pencegahan massal (POPM) filariasis (Info
Data dan Informasi Kementrian Kesehatan RI, 2015).

Keberadaan nyamuk yang berdekatan dengan kehidupan manusia dan hewan dapat menimbulkan masalah yang cukup serius dikarenakan nyamuk bertindak sebagai vektor beberapa penyakit yang sangat penting dengan tingginya tingkat kesakitan dan kematian yang ditimbulkannya. Cara yang paling cepat untuk memutuskan siklus penularan adalah secara kimiawi dengan menggunakan larvisida maupun insektisida sintetik,tetapi penggunaan senyawa tersebut dapat meningkatkan resistensi nyamuk, pencemaran lingkungan,bahkan kematian bukan sasaran (Sussanti, 2017).

Larvisida yang banyak digunakan oleh masyarakat luas adalah abate atau temefos.Penggunaan temefos sebagai larvisida sintetik sangat efektif dalam mengendalikan jentik (larva) nyamuk, tetapi penggunaan yang berulang dapat menimbulkan efek samping seperti gangguan pernapasan dan gangguan 
pencernaan pada manusia, sehingga dibutuhkan larvisida alternatif yaitu larvisida alami yang memiliki efektivitas yang sama baik dengan temefos. Penggunaan larvisida alami diharapkan tidak mempunyai efek samping terhadap lingkungan, manusia dan tidak menimbulkan resistensi bagi serangga (Soedarto,2008).

Dewasa ini strategi pencegahan dan pemberantasan vektor penyakit filariasis dilakukan dengan lebih memperhatikan lingkungan yang disebut integrated vector management (IVM). IVM dirancang untuk mengurangi dampak negatif terhadap lingkungan akibat penggunaan insektisida dan menekankan pentingnya memperhatikan ekologi vektor dan pola transmisi lokal. Hal tersebut dapat dilakukan dengan manajemen lingkungan dan pemberantasan vektor secara biologi (Departemen Kesehatan RI, 2003). Salah satu agen biologik yang dapat digunakan dalam pemberantasan vektor adalah Buah Pepaya (Carica Papaya L.). bagian biji pepaya (Carica Papaya L.) mengaundung berbagai senyawa kimia antara lain karpain, asam oleat, asam palmitat, asam linoleat, asam stearat, benzylglucosinolate, thiourea, banzylisothiocyante, behenic acid, benxylsenevol, karbohidrat, caricin, hexadecenoic acid, myrosin, protein, lemak, dan serat.(Rahayu,2014). Oleh karena itu, penulis lebih menekankan penelitian ini pada fungsi dari biji pepaya (Carica Papaya L.) yang di blender dan di haluskan menjadi alternatif pengganti abate sebagai jentik (larva)sida terhadap jentik (larva) Culex sp. yang bertindak sebagai vektor pada penyakit Filariasis.

Hasil penelitian tentang Efektifitas serbuk biji pepaya (Carica Papaya L) sebagai larvisida alami terhadap kematian jentik (larva) pada tahun 2009 yaitu Dosis yang paling efektif terhadap kematian jentik (larva) berada di dosis $200 \mathrm{mg} / 100$ $\mathrm{ml}$ air yang terbukti dapat membunuh sekitar $100 \%$ dari kematian jentik jentik (larva).(Utomo,2010).

Penelitian ini bertujuan untuk mengetahui efektivitas serbuk biji pepaya (Carica Papaya L.) terhadap kematian jentik (larva) Culex sp.

\section{METODE}

Populasi jentik (larva) Culex sp. diperoleh dari daerah Kp.Sirna Galih, kelurahan Karangsari Kecamatan Neglasari Kota Tangerang yang dikolonisasi di Laboratorium Parasitologi Jurusan Analis Kesehatan Poltekkes Kemenkes Banten. Sedangkan biji pepaya (Carica Papaya L.) didapatkan pada pasar tradisional Kutabumi Kota Tangerang. 
Sampel yang digunakan dalam satu konsentrasi yaitu 20 ekor jentik (larva). Jadi jumlah keseluruhan jentik (larva) yang dibutuhkan yaitu 600 ekor jentik (larva). Jentik Culex sp. dilakukan kolonisasi di Laboratorium Parasitologi.

Serbuk Biji Pepaya (Carica Papaya L) dari Biji Pepaya (Carica Papaya L) yang tidak rusak dan tidak berjamur dikeringkan selama 1 hari sampai benar-benar kering (tidak ada kandungan air),setelah itu di oven untuk memastikan benar-benar kering selama 2 jam pada suhu $38^{\circ} \mathrm{C}$, kemudian di blender hingga menjadi serbuk. Pembuatan Konsentrasi dosis serbuk Biji Pepaya (Carica Papaya L.) dengan menggunakan neraca analitik ditimbang serbuk biji pepaya (Carica Papaya L.) sebanyak $60 \mathrm{mg}, 90 \mathrm{mg}, 120$ mg,150 mg, kemudian ditambahkan kalium hipoklorit dengan perbandingan 3:1 ( 3 bagian serbuk biji pepaya dan 1 bagian kalium hipoklorit.) kemdian dicampurkan kedua bagian tersebut.

Uji efektifitas Serbuk Biji Pepaya (Carica Papaya L.) dilakukan dengan cara disiapkan 30 cup plastik berukuran $500 \mathrm{ml}$ yang bersih dan diberi label sesuai konsentrasi dosis, kemudian masingmasing wadah plastik dimasukan $250 \mathrm{ml}$ aquadest, di tambahkan serbuk biji pepaya (Carica Papaya L.) yang sudah dihaluskan menggunakan blender sesuai konsentraasi dosis, dan masukkan jentik (larva) Culex sp. sebanyak 20 ekor. Kemudian didiamkan selama 24 jam. Setelah 24 jam dilakukan pengamatan untuk menghitung berapa jumlah jentik (larva) yang mati untuk mengetahui hasil uji efektivitas dari Serbuk Biji Pepaya (Carica Papaya L.). Kontrol uji dalam penelitian ini menggunakan 1 kontrol yaitu kontrol negatif, dengan menambahkan $250 \mathrm{ml}$ aquadest dan 20 ekor jentik (larva) Culex sp. tanpa diberikan konsentrasi dosis Serbuk Biji Pepaya (Carica Papaya L.).

Data primer dari hasil pengamatan jumlah jentik (larva) Culex sp. yang mati diolah dengan menggunakan pola rancangan acak kelompok (RAK) yang disajikan dalam bentuk tabel dan grafik kemudian dianalisis menggunakan aplikasi SPSS dengan uji One Way ANNOVA.

\section{HASIL DAN PEMBAHASAN}

Data Penelitian Efektivitas Serbuk Biji Pepaya (Carica Papaya L.) terhadap kematian larva Culex sp. dengan wadah berisi 120 ekor larva terbagi dalam 6 pengulangan dalam beberapa konsentrasi dosis (60 mg, $90 \mathrm{mg}, 120 \mathrm{mg}$, dan $150 \mathrm{mg}$ ) dalam $250 \mathrm{ml}$ aquadest dengan enam kali pengulangan selama 24 jam adalah sebagai berikut : 
Jumlah Kematian larva Culex sp. dengan menggunakan serbuk biji pepaya (Carica Papaya L.) dan Kalium hipoklorit.
Hasil penelitian menunjukkan bahwa serbuk biji papaya dapat mematikan larva culex sp.Jumlah kematian terendah

\begin{tabular}{|c|c|c|c|c|c|c|c|c|c|c|}
\hline \multirow{2}{*}{$\begin{array}{l}\text { Konsen } \\
\text { trasi/25 } \\
0 \mathrm{ml}\end{array}$} & \multicolumn{6}{|c|}{ Pengulangan } & \multirow{2}{*}{$\begin{array}{c}\text { Jml } \\
\text { Larv } \\
\text { a } \\
\text { mati }\end{array}$} & \multirow{2}{*}{$\begin{array}{c}\text { Jml } \\
\text { Larva } \\
\text { Hidup }\end{array}$} & \multirow[t]{2}{*}{$\begin{array}{l}\text { Rata } \\
\text { mati }\end{array}$} & \multirow{2}{*}{$\begin{array}{c}\% \\
\text { Mati }\end{array}$} \\
\hline & 1 & 2 & 3 & 4 & 5 & 6 & & & & \\
\hline $60 \mathrm{mg}$ & 11 & 13 & 12 & 9 & 14 & 11 & 70 & 50 & 11,6 & $\begin{array}{l}58,3 \\
3 \%\end{array}$ \\
\hline $90 \mathrm{mg}$ & 16 & 17 & 13 & 15 & 16 & 17 & 94 & 26 & 15,6 & $\begin{array}{l}78,3 \\
3 \%\end{array}$ \\
\hline $120 \mathrm{mg}$ & 17 & 18 & 16 & 17 & 19 & 18 & 105 & 15 & 17,5 & $\begin{array}{l}87,5 \\
0 \%\end{array}$ \\
\hline $\begin{array}{c}150 \\
\mathrm{mg}\end{array}$ & 19 & 18 & 19 & 19 & 18 & 20 & 113 & 7 & 18,8 & $\begin{array}{c}94,1 \\
6 \%\end{array}$ \\
\hline $\begin{array}{c}\text { Kontro } \\
\text { l (-) }\end{array}$ & 0 & 0 & 0 & 0 & 0 & 0 & 0 & 120 & 0 & $\begin{array}{l}00,0 \\
0 \%\end{array}$ \\
\hline
\end{tabular}
yaitu terdapat pada konsentrasi $60 \mathrm{mg}$ sebanyak 70 ekor dengan rata-rata kematian sebesar 11,6 ekor larva dan kematian tertinggi pada konsentrasi $90 \quad \mathrm{mg}$ sejumlah 113 ekor dengan ratarata kematian sebesar 18,8 ekor larva. Jadi dapat diketahui bahwa semakin besar konsentrasi dosis maka jumlah kematian larva semakin banyak. Tingkat toksisitas dapat dinyatakan toksik karena Berdasarkan data yang diperoleh sebelumnya bahwa data berdistribusi normal dan variasi data homogen maka kedua syarat uji One Way ANOVA terpenuhi.

Tabel 5. Hasil Uji One Way ANOVA

\begin{tabular}{lccccc}
\hline & $\begin{array}{c}\text { Sum of } \\
\text { Squares }\end{array}$ & Df & $\begin{array}{c}\text { Sean } \\
\text { Square }\end{array}$ & F & Sig. \\
\hline $\begin{array}{l}\text { Between } \\
\text { Groups }\end{array}$ & 174,833 & 3 & 58,728 & 33,302 & 0,000 \\
\hline $\begin{array}{l}\text { Within } \\
\text { Groups }\end{array}$ & 35,000 & 20 & 1,750 & & \\
\hline Total & 209,833 & 23 & & & \\
\hline
\end{tabular}

Berdasarkan Tabel 5 hasil uji statistik di atas menunjukan hasil yang sangat signifikan, dengan nilai signifikasi yaitu sebesar $0.000 \quad(\mathrm{p}<0,05)$. Ada perbedaan tingkat konsentrasi dosis serbuk Biji Pepaya (Carica Papaya L.) terhadap kematian jentik (larva) Culex sp. dapat mematikan larva Culex sp. pada konsentrasi terendah yaitu konsentrasi 60 mg dengan jumlah kematian 70 ekor (konsentrasi dosis terendah sudah dapat yang paling efektif untuk membunuh larva Culex sp. yaitu pada konsentrasi $150 \mathrm{mg}$ dengan jumah kematian sebanyak 113 ekor larva $(94,16 \%)$.

Kematian larva Culex sp. sangat dipengaruhi oleh konsentrasi dosis, hal ini sesuai dengan penelitian yang dilakukan oleh Utomo (2010) bahwa konsentrasi dosis serbuk biji pepaya (Carica Papaya L.) sangat berpengaruh terhadap toksisitas dan lama residunya di dalam air. Hal ini dikarenakan semakin tinggi konsentrasi menunjukan angka kematian). Konsentrasi 
dosis serbuk biji pepaya (Carica Papaya L.) semakin banyak kematian larva Culex sp.oleh serbuk biji pepaya (Carica Papaya L.). Sementara pada kontrol negatif yang terdapat 120 ekor larva tanpa diberikan perlakuan dengan penambahan serbuk biji pepaya (Carica Papaya L.) tidak ditemukannya kematian, bahkan larva bisa berkembang menjadi stadium pupa dan ada pula yang berhasil menjadi nyamuk dewasa. Hal ini menyatakan bahwa larva dalam keadaan baik dan dapat menyingkirkan adanya kemungkinan faktor lain atau faktor perancu yang menyebabkan kematian pada kelompok perlakuan.

Berdasarkan hasil uji One Way ANOVA didapatkan signifikasi sebesar $0,000$ ( $\mathrm{p}<0,05)$, dapat di artikan bahwa "Ada perbedaan tingkat konsentrasi dosis serbuk Biji Pepaya (Carica Papaya L.) terhadap kematian larva Culex sp."

\section{Hasil Morfologi Culex sp.}

Pada penelitian ini larva Culex sp. yang digunakan yaitu larva instar III/IV. Larva instar III/IV sudah memiliki sistem pencernaan yang lengkap sehingga kematian larva dapat dipastikan karena perlakuan bukan karena pengaruh faktor luar. Sebelum dilakukan pengujian, dilakukan pengukuran pada larva menggunakan penggaris untuk memastikan bahwa larva yang digunakan yaitu larva instar III/IV. Larva instar III memiliki panjang sekitar 4-5 $\mathrm{mm}$ dan instar IV sekitar 5-6 mm (Haryono, 2015). Kemudian di lihat secara mikroskopis untuk memastikan bahwa larva yang digunakan adalah larva Culex sp. dengan ciri-ciri memiliki shifon 4 kali lebih panjang dengan ujung meruncing dibandingkan dengan larva yang lain.

\section{Hasil perlakuan larva Culex sp. pada serbuk biji pepaya (Carica Papaya $L$.)}

Kematian larva pada penelitian ini dipengaruhi oleh beberapa faktor, baik faktor dari kondisi larva maupun faktor lingkungan. Ditinjau dari kondisi larva, larva yang digunakan pada penelitian ini adalah instar III/IV dimana menurut Haryono (2015) menyatakan bahwa pada stadium ini sistem pencernaan larva sudah terbentuk dengan sempurna, sehingga alkaloid karpaina dan saponin pada serbuk biji pepaya (Carica Papaya L.) dapat bekerja dengan optimum sebagai racun atau toksin pada saluran pencernaan. Hasil tersebut sesuai dengan penelitian Wardani et.al (2010: 36), bahwa semakin tinggi konsentrasi serbuk yang diberikan maka semakin banyak pula kandungan minyak atsiri, flavonoid, alkaloid dan saponin yang diterima atau kontak langsung dengan larva pada media penelitian dan 
menyebabkan kematian larva instar III/IV Culex sp.Kematian larva instar III/IV Culex sp.dalam penelitian ini disebabkan oleh senyawa metabolik sekunder yang terdapat pada serbuk biji buah pepaya (Carica papaya L.) yaitu saponin, alkaloid,flavonoid dan tanin.

Senyawa saponin terkandung dalam tanaman pepaya (Carica Papaya L.) terutama banyak ditemukan pada bagian bijinya. Kandungan saponin pada serbuk biji buah pepaya (Carica Papaya L.) bekerja sebagai racun perut dimana zat tersebut dapat masuk ke tubuh larva melalui mulut (sistem pencernaan) kemudian meracuni larva tersebut. Selain itu, saponin juga berpengaruh sebagai racun kontak yang terlihat pada gangguan fisik larva bagian luar (kutikula), yaitu mencuci lapisan lilin yang melindungi tubuh larva dan menyebabkan kematian karena kehilanganbanyak cairan tubuh. Mekanisme kerja saponin sebagai larvasida juga diungkapkan oleh (Taufiq, 2015) yaitu dengan cara mendenaturasi protein dan enzim di dalam sel. Saponin dapat berdifusi melalui membran luar dan dinding sel yang rentan kemudian mengikat membran sitoplasma sehingga mengganggu dan mengurangi kestabilan membran sel. Hal ini menyebabkan sitoplasma bocor keluar dari sel yang mengakibatkan

kematian

sel.(Arismawati,2017).

Senyawa alkaloid juga dapat dimanfaatkan sebagai larvasida melalui cara kerja yang unik yaitu sebagai racun kontak (contac poisoning). Alkaloid berupa garam sehingga bisa mendegradasi membran sel kemudian masuk ke dalam dan merusak sel. Selain itu, alkaloid masuk ke dalam tubuh larva melalui absorbsi dan mendegradasi membran sel kulit. Cara kerja alkaloid yaitu dengan mendegradasi membran sel kemudian masuk ke dalam untuk merusak sel serta mengganggu kerja saraf larva dengan menghambat kerja enzim asetilkolin esterase. (Cania dan Setyaningrum ,2013)

Senyawa flavonoid yang terdapat pada ekstrak biji buah pepaya (Carica Papaya L.) juga dapat dimanfaatkan sebagai larvasida dengan cara mempengaruhi kerja sistem pernapasan larva atau sebagai racun pernapasan (fumigan). bahwa flavonoid masuk ke dalam tubuh larva melalui siphon yang berada dipermukaan air dan menimbulkan kelayuan pada saraf, serta menyebabkan kerusakan pada siphon akibatnya larva tidak bisa bernapas dan akhirnya mati. (Hapsari, 2012).

Kalium Hipoklorit mempengaruhi kualitas warna air menjadi jernih sehingga 
dapat mempengaruhi tempat berkembangbiak larva Culex sp. (Iskandar,2017).

Penggunaan serbuk biji buah pepaya (Carica papaya L.) sangat berpotensi dimanfaatkan sebagai biolarvasida karena memiliki kandungan senyawa metabolik sekunder berupa saponin, alkaloid, flavonoid dan tanin yang dapat menghambat bahkan mematikan larva instar III/IV Culex sp.melalui 3 cara yaitu sebagai racun perut (stomach poisoning), racun kontak (contac poisoning) serta sebagai racun pernapasan (fumigan).

(Arismawati,2017).

\section{SIMPULAN}

Berdasarkan hasil penelitian dapat disimpulkan bahwa:

1. Serbuk biji pepaya ( Carica Papaya L. ) mempunyai kemampuan untuk membunuh larva Culex sp.

2. Terdapat perbedaan tingkat kematian larva Culex sp. yang sangat signifikan diantara variasi konsentrasi serbuk biji pepaya ( Carica Papaya L. ) dengan persentase kematian terendah sebesar 70 ekor larva $(58,33 \%)$. Menyatakan bahwa pengaruh serbuk biji pepaya ( Carica Papaya L. ) terhadap kematian larva nyamuk Culex sp.
3. Konsentrasi yang paling efektif untuk membunuh larva Culex sp. yaitu pada konsentrasi $150 \mathrm{mg}$ dengan jumah kematian sebanyak 113 ekor larva $(94,16 \%)$.

\section{DAFTAR RUJUKAN}

Arismawati, Sawaluddin LOM, dan Sudrajat HW.2017. Efek Larvasida Ekstrak Biji Buah Pepaya (Carica papaya L.) terhadap Larva Instar III Aedes aegypti L.Jurnal Ilmiah Fakultas Kedokteran Universitas Halu Oleo.4(2):332-343.

Cania dan Setyaningrum. 2013. Uji Efektifitas Ekstrak Daun Legundi (Vitex trifolia) Terhadap Larva Aedes aegypti. Medical Journal of Lampung University. 2(4): 52-53.

CDC. 2016. Filariasis Scheme of The Life Cycle. http://www.dpd.cdc.gov/ dpdx/HTML/Filariasis.html. 03 Desember 2018 (14:07)

Departemen Kesehatan RI. 2003. Modul entomologi malaria 3. Bakti Husada. Jakarta

Departemen Kesehatan Republik Indonesia. 2006.Pedoman Penatalaksanaan Kasus Klinis Filariasis.Jakarta: Dirjen PPM \& PL, Departemen Kesehatan Republik Indonesia.

Dra. Shinta, Msi, dkk. 2014. Laporan Hasil Kajian Pemetaan Status Kerentanan Vektor Demam Berdarah Dengue Terhadap Insektisida dan Sejarah Penggunaan Insektisida di Indonesia. Pusat Teknologi Intervensi Kesehatan Masyarakat. Jakarta. 
Fitriana Nurhayani Haryono. 2015. Efikasi Kelambu Celup Cypermethrin 100 Ec terhadap Nyamuk Culex quinquefasciatus dari daerah bekasi. Skripsi. Program Kedokteran Universitas Islam Negeri Syarif Hidayatullah. Jakarta.

Ginting AM. Uji Dayaguna. 2005. Bacillus sphaericus terhadap Mortalitas Larva Culex quinquefasciatus, Aedes aegypti dan Anopheles aconitus di Laboratorium. Skripsi. Program Kedokteran Universitas Sebelas Maret. Surakarta.

Hapsari. 2012. Efektivitas Ekstrak Buah Belimbing (Averrhoa bilimbi L.) Terhadap Mortalitas Larva NyamukAedes aegypti. 1-8.

Haryono FN. 2015. Efikasi Kelambu Celup Cypemethrin 100 EC terhadap Nyamuk Culex quinquefasciatus dari Derah Bekasi Pada Tahun 2015. Skripsi. Program Kedokteran Universitas Islam Negeri Syarif Hidayatullah. Jakarta.

Iskandar I,Horiza H,Fauzi N.2017. Efektivitas Serbuk Biji Pepaya (Carica Papaya Linnaeaus) Sebagai Larvasida Alami Terhadap Kematian Larva Aedes Aegypty Tahun 2015.Eksakata.18(1):13-18.

Kementerian Kesehatan RI. 2015. Infodatin: Pusat Data dan Informasi Kesehatan RI. Kementrian Kesehatan RI. Jakarta.

Lestari,Y. 2016. Toksitas Campuran Ekstrak Daun Sirih (Piperbetle L.) dan biji pepaya (Carica papaya L.) Terhadap Mortilitas Larva Nyamuk Aedes aegypti L. Dan
Pemanfaatannya Sebagai Buku Ilmiah Populer. Skripsi.Program Studi Pendidikan Biologi. Universitas Jember.Jember.

Nafi'ah dan Sulistyowati. 2014.Penggunaan Ekstrak Biji Pepaya (Carica Papaya L)Sebagai Larvasida Nabati Terhadap Kematian Larva Nyamuk Anopheles dan Aedes aegypti Instar III. Jurnal STIGMA.07(01): 24-27.

Pusat Data dan Surveilans Epidemiologi Kemenkes RI. 2010. Filariasis di Indonesia. Buletin Jendela Epidemiologi. Jakarta.

Soedarto PG dan Khayan.2008.Parasitologi Klinik. AirlanggaUniversity press. Surabaya.

Rahayu, M.T.2014. Efektivitas Granula Etanol Biji Pepaya (Carica Papaya L). Terhadap Mortalitas Larva Nyamuk Aedes aegypti.skripsi. Jember:FKIP Biologi Universitas Jember.Jember.

Rukmana, Rahmat. 2003. Pepaya Budidaya Dan Pasca Panen. Kanisius. Yogyakarta.

Safar R. 2010. Edisi Khusus Parasitologi Kedokteran Protozoologi, Helmintologi, Entomologi. Yrama Widya. Bandung 